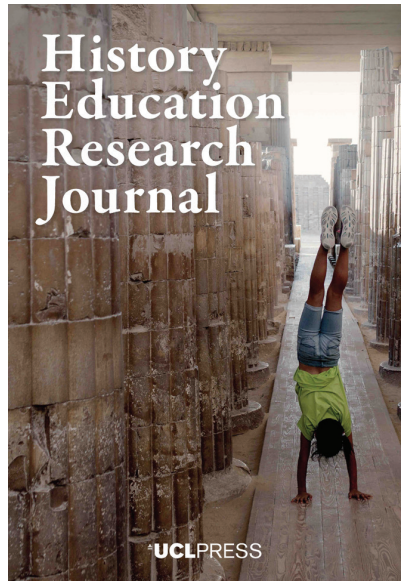

${ }^{\Perp}$ UCLPRESS

HISTORY EDUCATION RESEARCH JOURNAL

ISSN 2631-9713 (Online)

Journal homepage:

https://www.uclpress.co.uk/pages/history-educationresearch-journal

\title{
Retheorising national assessment of the narrative mode for historical causal explanation in England
}

\author{
James Edward CarrolliD
}

\section{How to cite this article}

Carroll, J.E. (2021) 'Retheorising national assessment of the narrative mode for historical causal explanation in England'. History Education Research Journal, 18 (2), 148-65. https://doi.org/10.14324/HERJ.18.2.02

Submission date: 10 January 2021

Acceptance date: 9 May 2021

Publication date: 19 October 2021

\section{Peer review}

This article has been peer-reviewed through the journal's standard double-blind peer review, where both the reviewers and authors are anonymised during review.

\section{Copyright}

(C) 2021 Carroll. This is an open-access article distributed under the terms of the Creative Commons Attribution Licence (CC BY) 4.0 https://creativecommons.org/licenses/by/4.0/, which permits unrestricted use, distribution and reproduction in any medium, provided the original author and source are credited.

\section{Open access}

The History Education Research Journal is a peer-reviewed open-access journal. 


\title{
Retheorising national assessment of the narrative mode for historical causal explanation in England
}

\author{
James Edward Carroll* - Esher Sixth Form College and UCL Institute \\ of Education, UK
}

\begin{abstract}
In history curriculum design in England, currently at least two loci of authority - the history teachers' 'extended writing movement' and the national awarding body Pearson Edexcel - present somewhat contrasting portrayals of the narrative mode for the purposes of historical causal explanation. Nonetheless, both loci suggest they are reappropriating academic knowledge for the purposes of secondary schooling in a fashion similar to what Basil Bernstein (1986) dubs 'recontextualisation'. As a practising history teacher, I provide a phenomenological critique of Pearson Edexcel's specifications for the national GCSE and A-level examinations from the perspective of the extended writing movement's realisation of the Bernsteinian model, with a specific focus on the narrative mode for the purposes of historical causal explanation. In order to characterise the status of historical narrative in the academic field of production, I draw on analytic philosophies of history, theories of history by practising historians and historical explanations from one historiography: the Salem witch trials. Finally, I make recommendations for future reforms in national history examinations in England: constant revaluation with reference to academic knowledge; the avoidance of specific yet unsustainable claims about the discipline of history generally; and the abandonment of a genre-led assessment in favour of an epistemology-led alternative.
\end{abstract}

Keywords: history, assessment, examinations, causation, narrative

\section{Introduction}

In the last twenty years in England, a discourse related to students' historical writing has emerged which has been dubbed the English history teachers' 'extended writing movement' (Counsell, 2011: 65-6). While this label is necessarily imperfect, and members of the 'movement' may not recognise themselves by such a term, the term can be applied to a group which has been largely, although not exclusively, teacher-led, and which has independently developed approaches to improving students' extended written arguments (Carroll, 2019).

The discourse of the extended writing movement is not grounded in large-scale research regarding how students currently write or the efficacy of these history teachers' approaches. Instead, the movement's participants have predominantly undertaken curricular theorising. The researchers in this prominent discourse have been influenced to some degree by Basil Bernstein's $(1981,1986)$ model for the creation of pedagogic knowledge (Carroll, 2019; Fordham, 2016). For Bernstein, pedagogic knowledge arises 
from the actions of specialised agents in three distinct settings. New knowledge is created in the field of 'production', which usually occurs in academic contexts. In order to be practicable for the purposes of schooling, however, academic knowledge must be transformed into pedagogic knowledge and be de-located (the selective reappropriation of a part of the academic discourse from the field of production) and re-located. This process takes place within the field of 'recontextualisation'. The final field is that of 'reproduction', where a pedagogic practice takes place in schools (Bernstein, 2000: 113-14).

Although they do not refer to 'recontextualisation', at least one awarding body in England who provide qualifications for the national General Certificate of Education (GCSE) (ages 14-16) and Advanced Level (A level) (ages 16-18) imply that their specifications selectively reappropriate academic knowledge: Pearson Edexcel suggest that they provide 'A Level qualifications that encourage students to think like historians' (Pearson Edexcel, 2015a: 2).

In this article, I will provide a phenomenological critique of Pearson Edexcel's specifications for the national GCSE and A-level examinations from the perspective of the extended writing movement's realisation of the Bernsteinian model, with a specific focus on the narrative mode for the purposes of historical causal explanation. In order to characterise the status of narrative in the field of production, I will draw on analytic philosophies of history, theories of history by practising historians and historical explanations from one historiography: the Salem witch trials. In light of my critique, I will make recommendations for future reforms in national history examinations in England: constant revaluation with reference to the field of production; the avoidance of specific yet unsustainable claims about the discipline of history generally; and the abandonment of a genre-led assessment in favour of an epistemology-led alternative.

\section{Characterisations of narrative}

'Narrative' was enshrined in the latest iteration of England's National Curriculum, with the government now expecting Key Stage 3 students during their compulsory secondary history education (ages 11-14) to 'create their own structured accounts, including written narratives' (DFE, 2013: 1). With the GCSE reforms first introduced in 2016, to achieve accreditation, awarding bodies were also obliged by the Department for Education (DfE) and the Office of Qualifications and Examinations Regulation (Ofqual) to include questions where students answer in the narrative mode (DfE, 2014: 6). According to Pearson Edexcel (2015b: 33-4), for example, 'the DfE criteria require students to be able to write narratives'. Similarly, a representative for Pearson Edexcel noted in a personal communication in April 2021, 'the approach to analytical narrative at GCSE was a DFE and Ofqual requirement and we had to ensure that our approach was in line with this'. These questions appear in Pearson Edexcel's Paper 2 Question 2, which begins with the formulaic genre-based question stem 'Write a narrative account analysing ...', such as 'Write a narrative account analysing the key events of 1519-21 leading to the Aztec surrender' (Pearson Edexcel, 2021: 55). According to the awarding body, these reforms were, in part, influenced by the views of academic historians. For example, the representative for Pearson Edexcel noted, 'when developing our specifications we consulted with a number of historians and we feel our approach is suitable for helping students to develop the necessary skills to be successful in this field of study'. At A level, however, awarding bodies are not obliged to include 'Write a narrative account ...' questions, and Pearson Edexcel do not.

In Pearson Edexcel's GCSE specifications, 'narrative' is presented in the following ways in relation to causal questions. First, 'narrative' - while it may causally explain - 
is also portrayed as different from 'causal explanation'. The use of the genre-based question stem 'Write a narrative account analysing ...', according to Pearson Edexcel, is to ensure that students can recognise that they must answer in a mode that is separate from 'causal explanation'. For example, Pearson Edexcel (2015c: 7) state that 'Paper $2 \mathrm{Q} 2$ targets analytical narrative, as required by the DfE. This is clearly signposted in the question stem to ensure students don't confuse it with questions requiring causal explanation'. Similarly, the representative from Pearson Edexcel suggested that:

the key to a good analytical narrative response is the construction of a logical and coherent chain of events which analyses the links between the events in order to create a narrative with a start, middle and end that essentially explains what happened. Students should approach this in a different way to a causal explanation. [My italics]

Second, 'narrative' is valued less than causal 'explanation'. 'Write a narrative account ...' questions are awarded only 8 marks, appreciably less than the higher-valued questions with 'explanatory' mode commands, such as 'Explain why ...' (12 marks) and '"[Statement]" How do you agree? Explain your answer' (20 marks) (Pearson Edexcel, 2015c: 7-8). For example, the representative of Pearson Edexcel noted that their 'questions are appropriately ramped in terms of difficulty and the number of marks attached. For this reason, it was felt appropriate to assign 8 marks to the analytical narrative question.' Furthermore, although Pearson Edexcel do not explicitly state in their A-level specification details or assessment rubrics that causal essay questions cannot be argued in the narrative mode, in their examiners' reports, teachers are explicitly advised that candidates should 'avoid a narrative/descriptive approach; this undermines the analysis that is required for the higher levels' (for example, Pearson Edexcel, 2017: 35; 2018: 41; 2019a: 51). Such guidance implies that A-level examiners operate with the assumption that narrative is separate from 'analysis'. Furthermore, it suggests that 'narrative' is lower order, and therefore that the mode, a priori, denies students the ability to access the highest levels of the awarding body's mark scheme.

Third, demands that students adopt the narrative mode precede any epistemological considerations that students might make. Students at GCSE are commanded to 'Write a narrative account ...' irrespective of the phenomenon to be causally explained. For example, Pearson Edexcel (2015b: 33-4) advise that 'the sample assessment materials indicate that the scope of a narrative may vary considerably in its chronology and that question wording may vary slightly, according to the narrative being sought'. 'Stimulus points', which are included in questions to act as 'signposts' for students as to what they may choose to include in their narrative, may be longterm, supra-personal and structural (for example, ideological conditions such as 'attitudes towards Mormons' (Pearson Edexcel, 2019b: 4)), or short-term individual actions (such as 'the actions of Nasser' (Pearson Edexcel, 2016: 166)). In short, students are commanded to write a narrative irrespective of the historical phenomenon being causally explained, the wording of the particular question or the student's particular argument.

Pearson Edexcel see their portrayal of narrative at GCSE as being influenced, in part, by the theorisation of some participants in the extended writing movement who, since the turn of the century, have sought to rehabilitate narrative as a mode of causal explanation (Carroll, 2019). For example, the representative of the awarding body noted that 'at GCSE the analytical narrative question was introduced as a brand new [sic] requirement in the last reforms because the History community felt that it was an under-appreciated skill'. Nonetheless, for the extended writing movement, 
the separation from, and attribution of lesser value to, the narrative compared to the 'analytical' mode is often not as pronounced as for Pearson Edexcel. Here, I have drawn on a definition of 'analytical mode' common in the field of production: a written mode which distils a historical phenomenon into constituent non-chronological parts, often by selecting the most significant, abstracted causal 'factors' that led to a specific consequence (Barzun and Graff, 1985; Black and MacRaild, 1997; Munz, 2006; Stone, 1987; Tamura, 2011). Using this definition, the analytical mode maps more neatly on to the genres that Pearson Edexcel expect students to employ in answer to causal questions with stems such as 'Explain why ...' and '"[Statement]" How do you agree? Explain your answer', rather than those with the stem 'Write a narrative account analysing ...'.

Particularly starting with Byrom (1998) and Lang (2003), a number of representatives of the history teachers' extended writing movement have questioned the dismissive manner in which the narrative mode has been deemed to be a 'lowerorder skill' (Hawkey, 2006: 1; for example, Foster and Goudie, 2019; Gadd, 2009; Kemp, 2012; Rodker, 2019; Worth, 2014). Lang (2003: 8), for instance, railed against the portrayal of 'mere' narrative by some teachers, examiners and policymakers, noting that 'it is difficult to think of any subject which so consistently and illogically denigrates its own central activity in the way that school history disregards and even penalises narrative'. For Lang (2003) and some other representatives of the extended writing movement, narrative is the main mode for causal explanation that academic historians employ, and it is highly explanatory, argumentative and interpretative. From such perspectives, which situate school history in the context of the public knowledge of academic scholarship, portrayal of 'narrative' as a foundational, lower-order skill are problematical. The majority of the ensuing history-teacher curriculum theorisation in this vein, however, has been at Key Stage 3 (ages 11-14). A possible reason for this imbalance may be the manner in which narrative has been portrayed by awarding bodies. Such portrayals may place restrictions on teachers - who otherwise might wish to employ academic historical writing as their cognate of success - because of a fear of damaging their students' achievements in national examinations.

\section{A phenomenological approach to competing loci of authority}

In history curriculum design in England, therefore, there are at least two competing loci of authority - the discourse of the extended writing movement and the awarding body Pearson Edexcel - which suggest, with varying degrees of explicitness and selfawareness, that they are 'recontextualising' the academic discipline of history. Despite such commonly stated aims, however, their respective visions of 'recontextualised' historical knowledge in the field of production in some cases differ from one another. Thus far, there has been little explicit discussion regarding the epistemological, practical and ethical challenges that the history curriculum designer encounters when confronted by influential yet somewhat contradictory recontextualising loci such as these.

I approach this issue from the perspective of a practising history curriculum designer adopting a phenomenological perspective (Gadamer, 1976; Heidegger, 1962; Macfarlane, 2003; Merleau-Ponty, 1962; Silverman, 1984; Spielberg, 1982; Van Manen, 1997). Phenomenologists stress the pre-understandings that interpreters bring to phenomena. In order to reflect on my lived experience of planning, teaching and assessing recontexualised historical causal arguments, in some respects I sought to 
push aside certain preconceptions regarding narrative that might limit my potential for (re)interpretations (Bryman, 1988; Counsell, 2009; Husserl, 1931; Marton, 1986; Palmer, 1969; Wolff, 1984). Such acculturation can result in deep-rooted and widespread reification: the confusion of 'the sense we make of things' with 'the way things are', and therefore the privileging of certain meanings to the exclusion of others (Crotty, 1998: 58-9). For example, existing concepts pertaining to historical causal explanation promoted by Pearson Edexcel appear to have possibly overly reduced, distorted or displaced the rich reality of historical causal explanation in the field of production that they are intended to describe. In some cases, the concept in the field of reproduction may even have substituted that from the field of production, perhaps leading to a situation for teachers 'living on top of a culture that has already become false' (Ortega y Gasset, 1958: 100). This trend may therefore also apply to some of the terminology in secondary history education: either in that such terminology has lost its original meaning in the field of production, or in that it has failed to adapt with changing meanings in academic history.

\section{Disagreement in field of production regarding historical narratives}

In terms of how and why historical inquiries should be conducted, in the field of production the discipline of history is extremely pluralistic, context-dependent and subject to change over time because of a lack of commonly agreed canons of knowledge, substantive objects of study, technical methods, theories and approaches (Black and MacRaild, 1997; Jordanova, 2000; Lambert and Schofield, 2004; Mabbett, 2007; Maza, 2017; Megill, 2007; Tosh, 2006). As the historian and theorist of history Mary Fulbrook (2007: 7) argues, 'the very plurality of approaches in history suggest there is in fact no single disciplinary approach'. For instance, the issue regarding the status of historical narrative for the purposes of causal explanation provoked the fiercest debate in analytic philosophy of history in the later twentieth century, with little consensus emerging (Carr, 2008; Dray, 2006; Roberts, 2001). As Ritter (1986: 279-82) notes:

... since the 1950s the issues surrounding the relationship of history and narrative - the art of storytelling and story forms - have been closely interwoven with the debate over the nature of historical explanation. The question has been approached in a wide variety of ways, and no consensus has thus far emerged.

In debates regarding historical narrative in both the fields of production and reproduction, much hinges on how 'narrative' is defined, with different definitions presupposing certain portrayals of the mode. Broadly, most appear to agree that narrative is a mode which involves the 'organisation of material in a chronologically sequential order, and the focusing of the content into a single coherent story, albeit with subplots' (Stone, 1987: 74-5). The defenders of narrative, however, tend to distinguish between what Walsh (1958) dubs 'plain' and 'significant' narratives. According to Hewitson (2015), much of the denigration of narrative stems from a failure to distinguish between the two. While the 'plain' narrative aims solely to 'give a description of facts restricted to a straightforward statement of what occurred', the 'significant' narrative aims 'to make clear not only what happened, but why it happened too' (Walsh, 1958: 480; Atkinson, 1978; Munz, 2006; Stanford, 1998). 'Significant' narrative is subject to empirical refutation; constructed rather than repeated; question-focused; purged of irrelevance (where the unanimously agreed criterion for relevance is the production 
of a satisfactory explanation of change); and provides new perspectives on previously asked questions, or answers new questions (Carr, 2008; Fulbrook, 2007). According to Hewitson (2015: 139), narrative 'in this restricted sense is the main form of causal, historical explanations'.

The extended writing movement and - to a certain extent in their GCSE specifications - Pearson Edexcel appear to view 'narrative' in a way congruent with the 'significant' definition. The representative from Pearson Edexcel, for instance, suggested that their:

... new question type is not simply a requirement to deploy knowledge of the period and say what happened. The stem for the question is not 'Write a narrative account' but 'Write a narrative account analysing...' ensuring there is a clear distinction between narrative and description.

Accordingly, a 'good historical narrative' 'seeks not only to describe what happened, but also to find connections and make sense of events so that there is analysis of why events unfolded in the way they did'. Nonetheless, Pearson Edexcel's portrayal of 'narrative' at A level appears to align more closely with the 'plain' definition, while at GCSE level the narrative mode is depicted as different to, and less explanatorily valuable than, 'causal explanation' in the analytical mode.

The panoply of views in the field of production presents a problem for the recontextualising history curriculum designer. If the designer attempts to recontextualise the academic analogue of history in such a way as to present principles to students that are universally true for all historians, the principles risk being so broad as to be pedagogically banal. Alternatively, if the recontextualiser attempts to be too specific, they are liable to misrepresent the fundamentally pluralistic nature of the historical discipline, which permits a variety of causal explanatory models (Megill, 2007). The latter approach might 'run the risk of freezing historical explanation in a kind of Procrustean bed that would present a glaring contrast with the present remarkable pluralism in the practice of explanation' (Van den Braembussche, 1989: 1).

\section{The 'eclipse of narrative': Narrative as non-explanatory and lower order}

For a history curriculum designer, there is some, albeit limited, scope to reconcile certain restrictions enforced by Pearson Edexcel with the academic cognate of history at a particular historical moment. Regarding narrative, Pearson Edexcel's particular model of causal explanation appears congruent with those which were especially popular among historians influenced by positivism and/or social scientific methodologies in the mid twentieth century - which presented narrative as a discrete, less explanatory, lower-order mode. This is not to say that the awarding body are consciously adopting such a model, but only that a model similar to that which was popular among certain historians in the mid twentieth century is now apparently being presented to students as paradigmatic of the discipline writ large in the twenty-first century. In the case of certain aspects of Pearson Edexcel's current examination specifications in England, therefore, the Procrustean-type processes discussed above appear, in some respects, to have already occurred.

'Anti-narrativism' - exemplified by interpretative frameworks particularly receptive to social-scientific methodologies such as Marxism, the French Annales school, Freudian psycho-history and cliometrics - became so influential that by the 1970s that it warranted, according to some observers, becoming paradigmatic 
orthodoxy (Barzun and Graff, 1985; Black and MacRaild, 1997; Munz, 2006; Stone, 1987; Tamura, 2011). Indeed, Ricoeur (1984: 95-6) dubbed this period as 'the eclipse of narrative'. Such critics of narrative, therefore, tended instead to recommend the 'analytic' mode (Furay and Salevouris, 2000; Roberts, 2001). Many anti-narrativists attacked the narrative mode for only being able to answer perceived unproblematic explicatory what and how questions, and not higher-valued explanatory why questions (Carr, 1986; McCullagh, 1969). As Roth (1988: 2) noted, in the positivist view, 'there exists a prima facie distinction between narratives and the standard form of a proper scientific explanation'. Such anti-narrativists, therefore, helped create a view that narrative inherently lacked explanatory power. Atkinson (1978: 136) observed, for example, that anti-narrativism led to 'the not uncommon belief that analytical history is explanatory in a higher degree than narrative'. More broadly, the 'anti-narrativists' helped create a perception that narrative was, in essence, lesser order. Megill (2007: 87-8), for instance, noted that such critiques contributed to 'the prevalent suspicion that narrative as such is epistemologically defective' [emphasis in the original].

This type of 'analytical' explanatory mode is particularly exemplified in the historiography of the Salem witch crisis in historians' writing in the 1970s and 1980s (Demos, 2008; Harrison, 2004). During this period, influential works by academics such as Demos (1970, 1982), Boyer and Nissenbaum (1976) and Karlsen (1989) explored 'the psychological, social and economic dimensions of the witchcraft crisis. Many have employed a number of social scientific techniques from a variety of disciplines, notably sociology, anthropology and psychology' (Gragg, 1992: 209). Accordingly, all of these works eschewed an overall narrative structure, with Salem Possessed by Boyer and Nissenbaum (1976) being indicative. Boyer and Nissenbaum (1976: 1-22) began their book with a separate narrative prologue of 'What happened in 1692'. The majority of the rest of the work, however, is divided into chapters which each focus on supra-personal preconditions that underlay the Salem witch crisis. These include the inability of local institutions to settle Salem Village's disputes; growing class tensions between an increasingly prosperous mercantile class in the east of Salem Village and the traditional agrarian class in the west; and growing factionalism in Salem Village led by the Porter and Putnam families. According to Greven Jr (1974: 513-14), by drawing on evidence 'ignored by narrative historians', Boyer and Nissenbaum (1976) were able to 'understand the experiences and patterns of life which preceded and undergirded the events of $1692^{\prime}$.

\section{The 'revival of narrative': Narrative as explanatory and higher order}

Pearson Edexcel's devaluing of narrative and its separation from causal explanation are, however, harder to justify if one looks at a different sample of historical causal explanation from the field of production. Narrative's strongest defence has come from philosophers who argue that the mode itself inheres an autonomous mode of historical explanation which owes little or nothing to the explanatory methods from other disciplines such as the social sciences (for example, Gallie, 1964; Renier, 1950). For example, Roth (1989: 459) claimed that:

... rather than attempting to look beyond conventions of narrative, perhaps the proper strategy is to insist that it is these very conventions which do the work of explanation. In this respect, narrative conventions are constitutive of historical practice and determinative of historical explanation. 
A pronounced example of the claim that the narrative mode itself inheres causal explanation comes from White $(1978,1999)$. Influenced by narrative theory in literary studies, White suggested that causal explanation at the macro level is regularly achieved through prefiguration, 'emplotting' the historian's perceptions of evidence into already widely understood narrative modes such as tragedy, romance, satire and comedy. For White (1973: 7), the historian achieves explanation as 'a sequence of events fashioned into a story [that] is gradually revealed to be a story of a particular kind'. Accordingly, for historians such as Munslow (2007: 38), 'if a history is emplotted as a tragedy, it is "explained" as a tragedy'.

In surveying such trends in analytic philosophy of history, the historian Geoffrey Roberts (2001: 3) went so far as to argue that by the twenty-first century:

... the defenders of narrative history were competing on much more equal terms with the continuing advocates of non-narrative, structuralist history. Indeed, among the philosophers, the ground had decisively shifted in favour of the so-called narrativists - those who considered that what was distinctive about the discipline of history was its storytelling character.

A similar 'revival of narrative' is visible among practising historians who theorised about history in the later twentieth century, particularly among historians who tended to favour individualist, action-based ontologies (for example, Stone, 1979; Elton, 1989; Hexter, 1972). From this perspective, narrative better explains phenomena that the 'analytical' mode necessarily marginalises, such as human intentions and actions (Black and MacRaild, 2007; Clark, 2013; Mabbett, 2007; Roberts, 2001; Turner, 1999); and chance, contingency and unintended consequences (Roberts, 1996). 'Nowadays', according to Roberts (2006: 203), 'talk about the value of narrative as a mode of explanation and understanding is ubiquitous in both academia and public discourse'.

In the historiography of the Salem witch trials in 1692, we encounter stark evidence of the 'revival', with a number of narratives of the crisis being published to coincide with the tricentenary of the trials (for example, Hoffer, 1996, 1997). In surveying the literature on the Salem trials at this time, for example, Demos (2008: 207-8) recognised a surge of 'narrative retellings of the trial sequence', a view substantiated by the books of the 1990s being titled as 'stories', such as those by Le Beau (The Story of the Salem Witch Trials, 1998), Hill (A Delusion of Satan: The full story of the Salem witch trials, 1996), and Rosenthal (Salem Story: Reading the witch trials of 1692, 1993). Similarly, Gragg (1992: ix) argued in the narrative mode in order to achieve, in his view, greater causal explanatory power by highlighting the importance of human agency in the trials:

I have adopted a narrative style that presents the events in chronological order. Within that framework, I have focused on the impact that individuals' decisions had on the outcome of events. This is an old-fashioned approach, one based on the belief that history is first and foremost a good story.

Far from being dismissed as being less explanatory, many of these works were judged explanatorily successful by the historians' peers precisely because of their narrative mode. Reviewing Gragg's (1992) book, Gildrie (1993: 640-1) suggested that 'There are distinct advantages to such an approach' because 'lack of interest in the nuances of individual character and choice is precisely why so many social science explanations, however clever, almost always seem abstract and clumsy'.

Furthermore, some in the field of production argue that chronological ordering can explain in a way that the analytical mode forbids (for example, Lowenthal, 1997; 
Atkinson, 1978). In such views, narrative is the best mode for emphasising change over time - a distinguishing characteristic of historical explanation compared to some other disciplines (Furet, 2001; Munz, 2006; Stanford, 1994, 1998). Tuchman (1981: 70), for instance, argued that when events 'are arranged in a sequence as strictly as possible, down to the week and day, sometimes even time and day, cause and effect which may have previously been obscure will become clear'.

We find evidence of the explanatory power of chronology in the historiography of the Salem witch trials when MacKenthun (1995: 257) praised Rosenthal's Salem Story (1993) for piecing:

... together 'elements of the narrative' in order to reveal a 'comprehensible tale', but also something like a 'developmental logic' of the Salem case. Taking on board the sociological theories of Boyer, Nissenbaum, and Karlsen, he also criticises their inability to grasp the complexity of the phenomenon. Rosenthal's own well-researched and sceptical 'reading' presents both a good (detective) 'narrative' and, in spite of his disclaimer, an implicit theory. Both are convincing due to the transparent organisation of the book, which discusses the development of the trials along the interrelated cases of each execution date.

MacKenthun (1995) praised Rosenthal's (1993) chronological structure for providing explanatory insight that had not been accessible to historians such as Boyer and Nissenbaum (1976) who employed the 'analytical' mode.

A further facet of the 'revival of narrative' has been some historians' emphasis on the difficulty of historical narrative, at least in its 'significant' guise (for example, Barzun and Graff, 1985; Lang, 2003; Marius and Page, 2007). Turner (1999: 302), for example, noted that:

... some advocates of what are now fashionably regarded as more sophisticated modes of scholarship seem to believe that producing an accurate narrative of past events that accounts for their causes is child's play, a simple task unsuitable for great minds. But anyone who has ever undertaken the taxing task of reconstructing a complex chapter of past happenings knows how naïve that notion is.

Indeed, some in the field of production have suggested that it is the analytical mode which encourages simplistic, stratified and monocausal explanations compared to narrative, which has more scope for interconnectivity and multicausality (for example, Elton, 1989; Fischer, 1970; Hexter, 1972; Stone, 1987). Stanford (1998: 104-5), for instance, asked 'when the parts have been examined, how can they be shown to fit together into the living whole that constitutes history?' Similarly, in the historiography of the Salem witch trials, Ray (2015: 13) deliberately narrated how the Salem witch trials occurred, rather than explaining why, in order to causally explain them and to avoid oversimplification:

This book, then, not only concerns the history of the Salem witch trials but it also lays bare some of the challenges of writing that history. It focuses on how the witch trials unfolded and less on the question of why, which is more limiting and often results in a simplistic verdict of a single cause. The Salem witch trials are not a 'cold case' to be solved but a tragedy to be investigated in all of its complexity of who, what, where, when, and how. 


\section{Explanatory ecumenicism}

Despite Pearson Edexcel's most recent examination specifications in England attributing lesser value to narrative and separating it from causal 'explanation', a consensus in the twenty-first century has not been reached in the field of production regarding the 'best' mode for historical causal explanation. The exclusivist, positivist claims of the mid twentieth century that history can only be causally explained in the 'analytical' mode currently do not appear tenable. Similarly, exclusivist claims that historical explanation can only be argued in the narrative mode have also drawn strong criticism (for example, Fischer, 1970; Goldstein, 1976; Helo, 2016; McCullagh, 1969). In the field of production, the failure of either anti-narrativists or revivalists to score a decisive victory has led to a current state of pragmatic ecumenicism regarding modes in historical causal explanation. Stone (1987: 75), for instance, argues that:

... history has always had many mansions and must continue to do so if it is to flourish in the future. The triumph of any one genre or school eventually always leads to narrow sectarianism, narcissism and self-adulation, contempt or tyranny towards outsiders, and other disagreeable and selfdefeating characteristics.

The irresolution of the debates regarding the importance of historical narrative for historical causal explanation in the field of production has had three corollaries of importance for the recontextualising history curriculum designer. First, in contrast to Pearson Edexcel's genre-based assessment, which actively restricts candidates from employing more than one mode, an ecumenical recognition now exists in the field of production that, when causally explaining, historians should not restrict themselves in this way (for example, Furay and Salevouris, 2000; Megill, 2007; Roberts, 2001, 2006; Stone, 1987; Tamura, 2011). Maza (2017: 197), for instance, has noted that 'while a majority of popular histories remain wedded to a traditional narrative form, most academic works engage, analytically, in a little of this and a little of that'.

For example, the sole adoption of one mode has been criticised by some historians for failing to enable the historian to argue the interrelationship between structural conditions and occasioning human actions (for example, Marwick, 2001). Accordingly, in order to enable explanation of causal interactivity, some historians advocate employing a 'synthesis' of modes (Burke, 1993: 237). Tosh (2006: 156) encapsulates this view:

The truth is that historians need to write in ways that do justice to both the manifest and the latent, both profound forces and surface events. And in practice this requires a flexible use of both analytical and narrative modes: sometimes in alternating sections, sometimes more completely fused throughout the text. This is in fact the way in which most academic historical writing is carried out today.

A second consequence of the irresolution of this debate, and in direct contradiction to Pearson Edexcel placing lesser value on narrative responses, has been a growing acceptance in the field of production that it is impossible to argue that either the 'narrative' or 'analysis' modes are inherently higher order. By the twenty-first century, Roberts (2001: 2) was arguing that:

... narrative history is a legitimate form of knowledge, at least on a par with other approaches to the study of the past, and constitutes a discipline as theoretically and philosophically sophisticated as any other in the human and social sciences. 
Finally, in contrast to Pearson Edexcel's use of genre-based command verbs such as 'Write a narrative account' being imposed on long-term and structural causal phenomena, in the field of production a pragmatic recognition has emerged that the historian's explanatory mode should not be an a priori decision, but should instead be based on epistemic criteria. Such criteria may include the particular question being asked, the interpretative framework being employed, the substantive topic under investigation and the argument to be made (Carr, 2008). Goldstein (1976: 142-3), for example, noted that:

It cannot be reasonable that the essential nature of the discipline is defined by the literary form in which its results are conveyed rather than by the kind of inquiry it is. That so many serious writers think that that is exactly how history is to be characterised is precisely the mark of how far conceptual analysis and the elucidation of modes of discourse have managed to submerge real epistemology.

In other words, for many historians, the choice of explanatory mode is a reaction to the type of phenomena that they are attempting to causally explain (Elton, 1989; Gaddis, 2002). For Stone (1987: 74-5), 'narrative is a mode of historical writing, but it is a mode which also affects and is affected by the content and the method'. Exclusive use of either mode in historical causal explanation - factorial analysis or narrative has been critiqued in the field of production for being reductionist, because particular modes are said to have greater explanatory power in different sub-disciplines of history. According to Tosh (2006: 154), for instance, 'the political sphere ... appears to lend itself so well to narrative' because political historians generally emphasise the importance of human agency as opposed to structural conditions. Accordingly, Atkinson (1978: 136) has argued for question-relativity when selecting modes because, in his view, 'the truth surely is that some questions require narrative, others analytic answers'.

Furthermore, because the same historical phenomenon can have different causal questions asked of it, which can be answered by employing different interpretative frameworks, a historian's choice of mode may be argument-driven: for example, to stress the relative causal importance of structural conditions vis-à-vis human actions or vice versa (Fulbrook, 2007). In other words, while a certain causal inquiry may lend itself to a particular mode, this relationship is not deterministic. The historian's mode can itself represent an argumentative decision. As Marius and Page (2007: 56-7) point out:

... keep in mind that argument, in the sense of developing a thesis, is fundamental to all the modes in writing history essays. The modes overlap, and you may use all of them in a single essay; certainly we have in our own writing ... when you write an essay, try to determine which modes will best advance your argument.

\section{Conclusion and recommendations}

As Maton and Muller (2007) note, limits exist in terms of Bernsteinian recontextualisation. These limits depend on 'evaluative rules' that ensure that pedagogised artefacts in the classroom continue to bear relation to their parent knowledge in the field of production (Maton and Muller, 2007: 28-9). Once the recontextualised artefact becomes too far divorced from its academic antecedent, it ceases to be the same subject. Furthermore, 
Van Manen (1997: 61) argues that linguistic terms can become 'silted, crusted, or fossilised' in such a way that original contact with the experiences that the language signified is broken. In the case of terms such as 'historical narratives' for the purpose of causal explanation, we find students aged 14 to 18 being asked to produce 'school history genres' with a tenuous relationship with their purported analogues in the field of production. As we have seen, assumptions that at least one awarding body treat as self-evident - that, in history, narrative is inherently separate from causal explanation, and that the former is of a lower order to the latter - are not substantiated by a survey of philosophies of history, theories of history by practising historians and authentic historical explanations by historians in at least one historiography from the later twentieth century onwards.

While the process of recontextualisation necessarily demands adapting the parent knowledge to make it practicable for the purposes of schooling, the fact that some history teachers - freed of the restrictions placed on them by examination specifications - have constructed Key Stage 3 (ages 11-14 years) history curricula more obviously founded on trends in the field of production might suggest that the issue is not simply one of the inability of younger students to access this particular academic knowledge (for example, Foster and Goudie, 2019; Gadd, 2009; Rodker, 2019; Worth, 2014).

If the history curriculum designer approaches the recontextualisation of historical narrative for causal explanation at the expense of practical/ethical considerations, they may feel obliged to construct curricula that make explicit to students that a historian's choice of mode(s) is dependent on epistemological criteria such as the question asked, the student's interpretative framework, the substantive phenomena under investigation and the student's particular argument. To do so with students studying national examinations such as the GCSE and A level, however, would in some cases jeopardise their chances of success - even if the student's response was closer to knowledge produced in the field of production. Furthermore, because of high-stakes accountability and awarding bodies' reputation as a locus of authority for 'school history', such characterisations of the discipline may have implications for history curriculum design for younger students, where the examination specifications should not yet apply. For example, genre-based pedagogies have derived warrant for their taxonomies of school history genres for younger students in part from analysis of examination specifications (for example, Christie and Derewianka, 2008).

The discipline of history is itself a historical phenomenon. The status of the narrative mode in the field of production has undergone substantial changes since the mid twentieth century, with further developments almost inevitable. A necessary lag while academic knowledge is recontextualised is unavoidable. In the case of developments in school history curriculum design since the early twenty-first century it appears that the 'revival of narrative' has manifested itself in history curriculum design in England in the form of the theorisation of the extended writing movement and governmental reforms at Key Stage 3 and, to a lesser extent, Key Stage 4/GCSE. While Stone, however, claimed to have identified the 'revival of narrative' in the field of production in 1979, awarding bodies' continued insistence that the narrative mode is fundamentally separate from explanation, and of an inherently lower order, persists. This is an issue that Coffin began to broach in 2004:

The question that emerges from these observations of the wider context is 'what are the implications for the recontextualisation of historical knowledge at the level of secondary schooling? Are school history genres 
stabilised for now? Or are they too evolving in response to the wider environment? (Coffin, 2004: 260)

For the recontextualising history curriculum designer, the discipline of history in the field of production is a moving target, with regular developments in areas such as substantive objectives of study, technical methods and interpretative frameworks. Inattention to such developments has resulted in national examinations continuing to privilege a particular conception of historical causal explanation that reached its apogee in the mid twentieth century, but which can no longer necessarily claim to be the dominant paradigm. In future, therefore, national examinations in history should be more explicitly and reiteratively referenced against developments in the field of production.

Not only is the discipline of history a moving target, but there are innumerable possible bullseyes for the recontextualising history curriculum designer to aim at, with many competing arguments available regarding which is the best to shoot for. As we have seen in the case of historical narrative for the purposes of causal explanation, practice in the field of production has become so pluralistic that it has led to a prevailing pragmatic ecumenicism. As a consequence, it is very difficult for a history curriculum designer to make a categorical claim about what historians do in the field of production that is both generally applicable and true. For example, while Pearson Edexcel state that candidates should 'avoid a narrative/descriptive approach; this undermines the analysis that is required for the higher levels' (for example, Pearson Edexcel, 2017: 35; 2018: 41; 2019a: 51), in the 1990s, a number of historians in the historiography of the Salem witch crisis employed the narrative approach precisely because, in their view, it provides greater explanatory power than the analytical mode (for example, Gragg, 1992; Hill, 1996; Hoffer, 1996, 1997; Le Beau, 1998; Rosenthal, 1993). In future, therefore, greater appreciation should be given to the essentially pluralistic nature of the historical discipline by ensuring that, if specific claims regarding historians' general practice are made, they are demonstrably substantiated with reference to the general practice in the field of production.

Finally, with command verbs necessitating responses in certain modes, in national examinations, genre is currently prioritised over epistemology. Instead, the prioritisation should be reversed, enabling students to employ the narrative or analytical mode (or a combination thereof) in light of the question being asked and the student's argument. In such a scenario, modes would not be demarcated or prioritised in terms of marks awarded. The merits of any causal explanation can only be judged in terms of its adequacy as a response to the particular question posed. Some philosophers have, therefore, noted that different types of causal questions may imply certain explanatory models in response, which in turn might have implications for the appropriacy of the mode (Atkinson, 1978; Mandelbaum, 1977; Van Bouwel and Weber, 2008).

For example, a candidate might be posed the following question and stimulus points, which demand focus on long-term structural conditions:

'It was the unusual political conditions operating in Massachusetts in 1692 that explain the extraordinary events in Salem.'

How far do you agree with this explanation of the Salem witch hunt of 1692 ?

You may use the following in your answer:

- The unusual political conditions operating in Massachusetts in 1692

- The Puritan world view.

Such a question, at least when the candidate discusses the structural conditions in the stimulus points, may perhaps be more amenable to a response in the analytic mode, 
although both modes should be permissible if the question set is answered. Similarly, a question more focused on shorter-term individual action might be asked, such as:

How far does the role of Governor Phips explain the end of the Salem witch hunt (1692-93)?

You may use the following in your answer:

- The role of Governor Phips

- The role of Increase Mather.

Such a question may lend itself more obviously to a narrative causal explanation, although successful responses in the analytic mode would also be credited. Finally, a question may be set so as to obviously permit either mode or combination thereof because a particular relevance relation is not built into it (Van Bouwel and Weber, 2008). Such questions would enable candidates to use the choice of mode as an argumentative choice to stress the relative causal importance of structural conditions in relation to individual actions or vice versa.

\section{Acknowledgements}

Many thanks to my PhD supervisors Arthur Chapman and Jim McKinley for their time, support and guidance. Thanks also to Christine Counsell for her comments and suggestions.

\section{Research ethics statement}

The author declares that research ethics approval for this article was provided by the Research Ethics Committee of UCL Institute of Education.

\section{Conflicts of interest statement}

The Editor-in-Chief of the History Education Research Journal, Arthur Chapman, is the author's doctoral supervisor. Besides this, the author declares no conflict of interest with this work.

\section{Notes on the contributor}

James Edward Carroll is a history teacher at Esher Sixth Form College, Thames Ditton, Surrey, UK. He is also a PhD candidate at the UCL Institute of Education, UK, researching literacy in history curriculum design. $\mathrm{He}$ is an associate editor for the professional journal Teaching History, and he participates in the History Subject Working Group for the new inspection framework of the Office for Standards in Education, Children's Services and Skills (Ofsted).

\section{References}

Atkinson, R.F. (1978) Knowledge and Explanation in History: An introduction to the philosophy of history. London: Macmillan.

Barzun, J. and Graff, H.F. (1985) The Modern Researcher. 4th ed. London: Harcourt Brace Jovanovich.

Bernstein, B. (1981) 'Codes, modalities, and the process of cultural reproduction: A model'. Language and Society, 10, 327-63. www.jstor.org/stable/4167260. 
Bernstein, B. (1986) 'On pedagogic discourse'. In J.G. Richardson (ed.), Handbook of Theory and Research for the Sociology of Education. New York: Greenwood Press, 205-40.

Bernstein, B. (2000) Pedagogy, Symbolic Control and Identity. London: Rowman and Littlefield.

Black, J. and MacRaild, D.M. (1997) Studying History. London: Macmillan.

Boyer, P. and Nissenbaum, S. (1976) Salem Possessed. Cambridge, MA: Harvard University Press.

Bryman, A. (1988) Quantity and Quality in Social Research. London: Routledge.

Burke, P. (ed.) (1993) New Perspectives on Historical Writing. Cambridge: Polity Press.

Byrom, J. (1998) 'Working with sources: Scepticism or cynicism? Putting the story back together again'. Teaching History, 91, 32-5. www.jstor.org/stable/26236922.

Carr, D. (1986) Time, Narrative, and History. Bloomington: Indiana University Press.

Carr, D. (2008) 'Narrative explanation and its malcontents'. History and Theory, 47 (1), 19-30. https://doi.org/10.1111/j.1468-2303.2008.00433.x.

Carroll, J.E. (2019) 'Epistemic explanations for divergent evolution in discourses regarding students' extended historical writing in England'. Journal of Curriculum Studies, 51 (1), 100-20. https://doi.org/10.1080/00220272.2018.1499805.

Christie, F. and Derewianka, B. (2008) School Discourse. London: Continuum.

Clark, C. (2013) The Sleepwalkers: How Europe went to war in 1914. London: Penguin.

Coffin, C. (2004) 'Learning to write history: The role of causality'. Written Communication, 21 (3), 261-89. https://doi.org/10.1177\%2F0741088304265476.

Counsell, C. (2009) 'Interpretivism: Meeting our selves in research'. In E. Wilson (ed.), School-Based Research: A guide for education students. London: Sage, 251-76.

Counsell, C. (2011) 'History teachers as curriculum makers: Professional problem-solving in secondary school history in England'. In B. Schüllerqvist (ed.), Patterns of Research in Civics, History, Geography and Religious Education. Karlstad: Karlstad University Press, 53-88.

Crotty, M. (1998) The Foundations of Social Research. London: Sage.

Demos, J. (1970) 'Underlying themes in the witchcraft of seventeenth-century New England'. The American Historical Review, 75 (5), 1311-26. https://doi.org/10.1086/ahr/75.5.1311.

Demos, J. (1982) Entertaining Satan: Witchcraft and the culture of early New England. Oxford: Oxford University Press.

Demos, J. (2008) The Enemy Within: 2,000 years of witch-hunting in the Western World. London: Viking.

DfE (Department for Education) (2013) History Programmes of Study: Key Stage 3 National Curriculum in England. Accessed 13 July 2021. https://assets.publishing.service.gov.uk/ government/uploads/system/uploads/attachment_data/file/239075/SECONDARY_national_ curriculum_-_History.pdf.

DfE (Department for Education) (2014) History: GCSE subject content. Accessed 13 July 2021. https://assets.publishing.service.gov.uk/government/uploads/system/uploads/attachment_data/ file/310549/history_GCSE_formatted.pdf.

Dray, W. (2006) 'Philosophy and historiography'. In M. Bentley (ed.), Companion to Historiography. London: Routledge, 763-82.

Elton, G.R. (1989) The Practice of History. London: Fontana.

Fischer, D.H. (1970) Historians' Fallacies: Towards a logic of historical thought. New York: Harper Perennial.

Fordham, M. (2016) 'Realising and extending Stenhouse's vision of teacher research: The case of English history teachers'. British Educational Research Journal, 42 (1), 135-50. https://doi.org/10.1002/berj.3192.

Foster, R. and Goudie, K. (2019) 'a b c D e?: Teaching Year 9 to take on the challenge of structure in narrative'. Teaching History, 175, 28-38. Accessed 13 July 2021. www.history.org.uk/publications/ resource/9614/teaching-year-9-to-take-on-the-challenge-of-struct.

Fulbrook, M. (2007) Historical Theory. London: Routledge.

Furay, C. and Salevouris, M.J. (2000) The Methods and Skills of History: A practical guide. 2nd ed. Wheeling, IL: Harland Davidson.

Furet, F. (2001) 'From narrative history to problem-oriented history'. In G. Roberts (ed.), The History and Narrative Reader. London: Routledge, 269-80.

Gadamer, H-G. (1976) Philosophical Hermeneutics. Berkeley: University of California Press.

Gadd, S. (2009) 'Building memory and meaning: Supporting Year 8 in shaping their own big narratives'. Teaching History, 136, 34-41. Accessed 13 July 2021. www.history.org.uk/secondary/ resource/2693/building-memory-and-meaning.

Gaddis, J. (2002) The Landscape of History: How historians map the past. Oxford: Oxford University Press. 
Gallie, W.B. (1964) Philosophy and the Historical Understanding. London: Chatto and Windus.

Gildrie, R.P. (1993) 'Reviewed works(s): The Salem Witch Crisis by Larry Gragg'. Journal of American History, 80 (2), 640-1. https://doi.org/10.2307/2079895.

Goldstein, L.J. (1976) Historical Knowing. London: University of Texas Press.

Gragg, L. (1992) The Salem Witch Crisis. London: Prager.

Greven, Jr, P.J. (1974) 'Salem probed: Salem Possessed: The social origins of witchcraft by Paul Boyer and Stephen Nissenbaum'. Reviews in American History, 2 (4), 513-18. https://doi.org/10.2307/2701067.

Harrison, R. (2004) 'History and sociology'. In P. Lambert and P. Schofield (eds), Making History: An introduction to the history and practices of a discipline. London: Routledge, 138-49.

Hawkey, K. (2006) 'Mediating narrative in classroom history'. International Journal of History Learning, Teaching and Research, 6 (1), 1-10.

Heidegger, M. (1962) Being and Time. Oxford: Basil Blackwell.

Helo, A. (2016) 'Letting go of narrative history: The linearity of time and the art of recounting the past'. European Journal of American Studies, 11 (2). https://doi.org/10.4000/ejas.11648.

Hewitson, M. (2015) History and Causality. London: Palgrave Macmillan.

Hexter, J.H. (1972) The History Primer. London: Allen Lane.

Hill, F. (1996) A Delusion of Satan: The full story of the Salem witch trials. London: Penguin.

Hoffer, P.C. (1996) The Devil's Disciples: Makers of the Salem witch trials. London: Johns Hopkins University Press.

Hoffer, P.C. (1997) The Salem Witchcraft Trials: A legal history. Lawrence: University of Kansas Press.

Husserl, E. (1931) Ideas: General introduction to pure phenomenology. London: Sage.

Jordanova, L. (2000) History in Practice. London: Arnold.

Karlsen, C.F. (1989) The Devil in the Shape of a Woman: Witchcraft in colonial New England. New York: Vintage.

Kemp, R. (2012) 'Thematic or sequential analysis in causal explanations?: Investigating the kinds of historical understanding that Year 8 and Year 10 demonstrate in their efforts to construct narratives'. Teaching History, 145, 32-43. Accessed 13 July 2021. www.history.org.uk/secondary/ resource/5128/thematic-or-sequential-analysis-in-causal-explanat.

Lambert, P. and Schofield, P. (eds) (2004) Making History: An introduction to the history and practices of a discipline. London: Routledge.

Lang, S. (2003) 'Narrative: The under-rated skill'. Teaching History, 110, 8-15. Accessed 13 July 2021. www.history.org.uk/secondary/resource/60/narrative-the-under-rated-skill.

Le Beau, B.F. (1998) The Story of the Salem Witch Trials. Upper Saddle River, NJ: Prentice Hall.

Lowenthal, D. (1997) The Past is a Foreign Country. Cambridge: Cambridge University Press.

Mabbett, I.W. (2007) Writing History Essays: A student's guide. Basingstoke: Palgrave Macmillan.

Macfarlane, R. (2003) Mountains of the Mind: The history of a fascination. London: Granta.

MacKenthun, G. (1995) 'Reviewed work(s): Salem Story: Reading the witch trials of 1692 by Bernard Rosenthal'. Journal of American Studies, 29 (2), 257-8.

Mandelbaum, M. (1977) The Anatomy of Historical Knowledge. London: Johns Hopkins University Press.

Marius, R. and Page, M.E. (2007) A Short Guide to Writing about History. London: Pearson Longman.

Marton, F. (1986) 'Phenomenography: A research approach to investigating different understandings of reality'. Journal of Thought, 21 (3), 28-49. https://www.jstor.org/stable/42589189.

Marwick, A. (2001) The New Nature of History: Knowledge, evidence, language. London: Palgrave.

Maton, K. and Muller, J. (2007) 'A sociology for transmission of knowledges'. In F. Christie and J.R. Martin (eds), Language, Knowledge and Pedagogy. London: Continuum, 14-33.

Maza, S. (2017) Thinking about History. London: University of Chicago Press.

McCullagh, C.B. (1969) 'Narrative and explanation in history'. Mind, 78 (310), 256-61. https://doi.org/10.1093/mind/LXXVIII.310.256.

Megill, A. (2007) Historical Knowledge, Historical Error: A contemporary guide to practice. London: University of Chicago Press.

Merleau-Ponty, M. (1962) Phenomenology of Perception. London: Routledge \& Kegan Paul.

Munslow, A. (2007) Narrative and History. Basingstoke: Palgrave Macmillan.

Munz, P. (2006) 'The historical narrative'. In M. Bentley (ed.), Companion to Historiography. London: Routledge, 851-72.

Ortega y Gasset, J. (1958) Man and Crisis. New York: Norton.

Palmer, R.E. (1969) Hermeneutics: Interpretation theory in Schleiermacher, Dilthey, Heidegger, and Gadamer. Evanston, IL: Northwestern University Press. 
Pearson Edexcel (2015a) Your guide to AS and A level History from 2015. Accessed 2 August 2021. https://qualifications.pearson.com/content/dam/pdf/A\%20Level/History/2015/teaching-andlearning-materials/A-\%20guide-to-AS-and-A-level-History-from-2015.pdf.

Pearson Edexcel (2015b) Getting Started Guide: GCSE (9-1) History - Pearson Edexcel Level 1/ Level 2 GCSE (9-1) in History (1HIO). Accessed 2 August 2021. https://qualifications.pearson.com/ content/dam/pdf/GCSE/History/2016/misc/gcse-history-getting-started.pdf.

Pearson Edexcel (2015c) How Our Assessments Give Every Student the Chance to Succeed: GCSE (9-1). Accessed 2 August 2021. https://qualifications.pearson.com/content/dam/pdf/GCSE/ History/2016/Teaching-and-learning-materials/gcse-9-1-history-assessment-guide.pdf.

Pearson Edexcel (2016) Paper 2 Specimen Papers: History - Pearson Edexcel Level 1/Level 2 GCSE (9-1) in History (1HIO). Accessed 21 July 2021. https:/qualifications.pearson.com/content/dam/ pdf/GCSE/History/2016/specification-and-sample-assessments/gcse-history-paper-2-specimenpapers.pdf.

Pearson Edexcel (2017) Examiners' Report June 2017: GCE History $9 H I 0$ 33. Accessed 21 July 2021. https://qualifications.pearson.com/content/dam/pdf/A-Level/History/2015/Exammaterials/9HIO_33_pef_20170816.pdf.

Pearson Edexcel (2018) Examiners' Report June 2018: GCE History 9HIO 33. Accessed 21 July 2021. https://qualifications.pearson.com/content/dam/pdf/A-Level/History/2015/Exammaterials/9HI0_33_pef_20180815.pdf.

Pearson Edexcel (2019a) Examiner Report - Option 33 - June 2019. Option 33 - The witch craze in Britain, Europe and North America, c1580-c1750. Accessed 2 August 2021. https://qualifications. pearson.com/content/dam/secure/silver/all-uk-and-international/a-level/history/2015/exammaterials/9HI0_33_pef_20190815.pdf (requires login).

Pearson Edexcel (2019b) Pearson Edexcel GCSE (9-1) 1HIO/P3 The American West, c1835-c1895. Accessed 2 August 2021. https://qualifications.pearson.com/content/dam/secure/silver/all-ukand-international/gcse/history/2016/exam-materials/1HI0_P3_que_20190607.pdf (requires login).

Pearson Edexcel (2021) GCSE (9-1) History: Sample Assessment Materials (Question Papers) Pearson Edexcel Level 1/Level 2 GCSE (9-1) in History (1HIO). First teaching from September 2016. First certification from 2018. Issue 3. Accessed 21 July 2021. https://qualifications.pearson. com/content/dam/pdf/GCSE/History/2016/specification-and-sample-assessments/GCSE_(91)_History_SAMs_MS_Issue_3.pdf.

Ray, B.C. (2015) Satan and Salem: The witch-hunt crisis of 1692. London: University of Virginia Press. Renier, G.J. (1950) History: Its purpose and method. London: Allen and Unwin.

Ricoeur, P. (1984) Time and Narrative Volume 1. Chicago, IL: University of Chicago Press.

Ritter, H. (1986) Dictionary of Concepts in History. London: Greenwood Press.

Roberts, G. (1996) 'Narrative history as a way of life'. Contemporary History, 31 (1), 221-8. https://doi.org/10.1177/002200949603100111.

Roberts, G. (ed.) (2001) The History and Narrative Reader. London: Routledge.

Roberts, G. (2006) 'History, theory and the narrative turn in IR'. Review of International Studies, 32 (4), 703-14. https://doi.org/10.1017/S0260210506007248.

Rodker, A. (2019) 'Austin's narrative: An exploratory case study, with Year 8, into what kinds of feedback help students produce better historical narratives of the interwar years'. Teaching History, 174, 8-15. Accessed 13 July 2021. www.history.org.uk/secondary/categories/611/ resource/9567/what-kinds-of-feedback-help-students-produce-bette.

Rosenthal, B. (1993) Salem Story: Reading the witch trials of 1692. Cambridge: Cambridge University Press.

Roth, P.A. (1988) 'Narrative Explanations: The case of history'. History and Theory, 27 (1), 1-13. https://www.jstor.org/stable/41303866.

Roth, P.A. (1989) 'How narratives explain'. Social Research, 56 (2), 449-78. https://www.jstor.org/ stable/40970551.

Silverman, H.J. (1984) 'Phenomenology: From hermeneutics to deconstruction'. Research in Phenomenology, 14, 19-34. https://doi.org/10.1163/156916484X00024.

Spielberg, H. (1982) The Phenomenological Movement: A historical introduction. Boston: Martinus Nijjoff.

Stanford, M. (1994) A Companion to the Study of History. Oxford: Blackwell.

Stanford, M. (1998) An Introduction to the Philosophy of History. Oxford: Blackwell.

Stone, L. (1979) 'The revival of narrative: Reflections on a new old history. Past \& Present, 85 (1), 3-24. https://doi.org/10.1093/past/85.1.3.

Stone, L. (1987) The Past and the Present Revisited. London: Routledge \& Kegan Paul. 
Tamura, E.H. (2011) 'Narrative history and theory'. History of Education Quarterly, 51 (2), 150-7. https://doi.org/10.1111/j.1748-5959.2011.00327.x.

Tosh, J. (2006) The Pursuit of History: Aims, methods and new directions in the study of modern history. London: Pearson.

Tuchman, B. (1981) Practicing History. New York: Ballantine Books.

Turner, H.A. (1999) 'Human agency and impersonal determinants in historical causation: A response to David Lindenfeld'. History and Theory, 38 (3), 300-6. https://doi.org/10.1111/0018-2656.00093.

Van Bouwel, J. and Weber, E. (2008) 'A pragmatist defense of non-relativistic explanatory pluralism in history and social science'. History and Theory, 47 (2), 168-82. https://www.jstor.org/ stable/25478743.

Van den Braembussche, A.A. (1989) 'Historical explanation and comparative method: Towards a theory of the history of society'. History and Theory, 28 (1), 1-24. https://doi.org/10.2307/2505267.

Van Manen, M. (1997) Researching Lived Experience: Human science for an action sensitive pedagogy. Toronto: Althouse Press.

Walsh, W.H. (1958) "'Plain" and "significant" narrative in history'. The Journal of Philosophy of History, 55, 479-84. https://doi.org/10.2307/2022239.

White, H. (1973) Metahistory: The historical imagination in nineteenth-century Europe. Baltimore, MD: Johns Hopkins University Press.

White, H. (1978) Tropics of Discourse: Essays in cultural criticism. Baltimore: Johns Hopkins University Press.

White, H. (1999) 'The fictions of factual representation'. In A. Green and K. Troups (eds), The Houses of History: A critical reader in twentieth-century history and theory, 214-29. Manchester: Manchester University Press.

Wolff, K.H. (1984) 'Surrender-and-catch and phenomenology'. Human Studies, 7 (2), 191-2. https://doi.org/10.1007/BF02633655.

Worth, P. (2014) '"English king Frederick I won at Arsuf, then took Acre, then they all went home": Exploring the challenges involved in reading and writing historical narrative'. Teaching History, 156, 8-19. 